\section{Evaluation of plasma homocysteine level according to the C677T and A1298C polymorphism of the enzyme MTHRF in type 2 diabetic adults}

\author{
Avaliação da homocisteína plasmática de acordo com o polimorfismo \\ C677T e A1298C da enzima MTHRF em adultos diabéticos tipo 2
}

Adriana Lima Mello', Selma Freire de Carvalho da Cunha², Maria Cristina Foss-Freitas ${ }^{3}$, Helio Vannucchi ${ }^{2}$

\begin{abstract}
Objective:To determine plasma homocysteine levels during fasting and after methionine overload, and to correlate homocysteinemia according to methylenetetrahydrofolate reductase (MTHFR) polymorphism in type 2 diabetic adults. Subjects and methods: The study included 50 type 2 diabetic adults (DM group) and 52 healthy subjects (Control group). Anthropometric data, and information on food intake, serum levels of vitamin $\mathrm{B}_{12}$, folic acid and plasma homocysteine were obtained. The identification of $\mathrm{C} 677 \mathrm{~T}$ and $\mathrm{A} 1298 \mathrm{C}$ polymorphisms was carried out in the MTHFR gene. Results: There was no significant difference in homocysteinemia between the two groups, and hyperhomocysteinemia during fasting occurred in $40 \%$ of the diabetic patients and in $23 \%$ of the controls. For the same polymorphism, there was not any significant difference in homocysteine between the groups. In the Control group, homocysteinemia was greater in those subjects with C677T and A1298C polymorphisms. Among diabetic subjects, those with the A1298C polymorphism had lower levels of homocysteine compared with individuals with C677T polymorphism. Conclusion: The MTHFR polymorphism (C677T and $\mathrm{A} 1298 \mathrm{C}$ ) resulted in different outcomes regarding homocysteinemia among individuals of each group (diabetic and control). These data suggest that metabolic factors inherent to diabetes influence homocysteine metabolism. Arq Bras Endocrinol Metab. 2012;56(7):429-34
\end{abstract}

Keywords

Diabetes; homocysteine; methylenetetrahydrofolate reductase; polymorphism

\section{RESUMO}

Objetivo: Determinar os níveis plasmáticos de homocisteína de jejum e após sobrecarga de metionina e correlacionar a homocisteinemia com o polimorfismo C677T e A1298C da metilenotetra-hidrofolato redutase (MTHFR) em diabéticos tipo 2. Sujeitos e métodos: 0 estudo incluiu 50 adultos diabéticos tipo 2 (Grupo DM) e 52 indivíduos saudáveis (Grupo controle). Obtiveram-se os dados antropométricos, de ingestão alimentar, níveis séricos de vitamina $\mathrm{B}_{12}$, ácido fólico $\mathrm{e}$ homocisteína plasmática. Os polimorfismos C677T e A1298C foram identificados no gene da enzima MTHFR. Resultados: Não houve diferença na homocisteinemia entre os grupos, embora a hiper-homocisteinemia de jejum tenha ocorrido em $40 \%$ dos diabéticos e $23 \%$ dos controles. Para o mesmo polimorfismo, não houve diferenças na homocisteinemia entre os grupos de estudo. Nos controles, a homocisteína foi maior entre aqueles com polimorfismos C677T e A1298C. Os diabéticos com polimorfismo A1298C apresentaram menores níveis de homocisteína quando comparados àqueles com polimorfismo C677T. Conclusão: Os polimorfismos da MTHFR (C677T e $\mathrm{A} 1298 \mathrm{C}$ ) resultaram em resposta distinta na homocisteinemia entre os indivíduos dentro de cada grupo (diabéticos e controles). Os dados sugerem que fatores metabólicos inerentes ao estado diabético influenciam o metabolismo da homocisteína. Arq Bras Endocrinol Metab. 2012;56(7):429-34

Descritores

Diabetes; homocisteína; metilenotetra-hidrofolato redutase; polimorfismo
'Department of Sciences of Nutrition, School of Nutrition, Universidade Federal da Bahia (UFBA), Salvador, BA, Brazil 2 Division of Nutrology, Faculdade de Medicina de Ribeirão Preto, Universidade de São Paulo (FMRPUSP), Ribeirão Preto, SP, Brazil ${ }^{3}$ Division of Endocrinology, FMRPUSP, Ribeirão Preto, SP, Brazil

Correspondence to: Helio Vannucchi Departamento de Medicina Interna, Faculdade de Medicina de Ribeirão Preto, Universidade de São Paulo Av. Bandeirantes, 3900 14048-900 - Ribeirão Preto, SP, Brazil hvannucc@fmrp.usp.br

Received on Feb/10/2011 Accepted on Aug/30/2012 


\section{INTRODUCTION}

Cardiovascular involvement in diabetes has been attributed to fluctuations in glycemic levels and to risk factors, such as systemic arterial hypertension, smoking, obesity, insulin resistance, microalbuminuria, and dyslipidemia (1). In addition, elevation in plasma homocysteine levels has been considered an independent cardiovascular risk factor, contributing to increased morbidity and mortality among diabetic patients (2). Endothelial injury secondary to hyperhomocysteinemia may be due to greater production of reactive oxygen species, to platelet activation, to smooth muscle cell proliferation, and to thrombotic phenomena $(3,4)$.

Several factors have been pointed out as determinants of hyperhomocysteinemia, such as folate, vitamin $\mathrm{B}_{6}$ and vitamin $B_{12}$ deficiencies (5), impaired renal function (6), hypothyroidism (7), as well as genetic predisposition. Hyperhomocysteinemia has been attributed to genetic defects of the remethylation pathway responsible for the conversion of homocysteine to methionine, or of the transsulfuration pathway, which converts homocysteine to cysteine. The abnormal increase in homocysteine after methionine overload indicates disorders of the transsulfuration pathway (8).

The main genetic causes of hyperhomocysteinemia are mutations resulting in deficiency of the enzymatic activity of methylenetetrahydrofolate reductase (MTHFR), of cystathionine beta-synthase (CBS) and, to a lesser extent, of methionine synthase (MS) $(9,10)$. C677T and A1298C gene polymorphisms of enzyme MTHFR interfere with the remethylation pathway and cause an increase plasma homocysteine during fasting $(11,12)$.

The aim of this study was to assess plasma levels of homocysteine under fasting and after methionine overload, besides analyzing hyperhomocysteinemia during fasting, according to enzyme MTHFR gene polymorphism in type 2 diabetes patients and control subjects.

\section{MATERIALS AND METHODS}

\section{Subjects}

This study was conducted on 50 type 2 diabetes patients (DM group) followed up at the diabetes outpatient clinic of a university hospital. Mean patient age was $48.2 \pm 7.6$ years, $70 \%$ were females and $62 \%$ had been diagnosed with diabetes 10 years or less before the study. The Control group consisted of 52 healthy individuals aged $38.9 \pm 8.6$ years, $57.7 \%$ females, with fasting glycemia within the normal range. Subjects who showed active infectious diseases, acute inflammatory disease, and renal insufficiency, were pregnant and nursing, and individuals with mental, hearing and visual disabilities, smokers, alcohol drinkers and subjects taking vitamin supplements were excluded from the study. The protocol was approved by the ethics committee of the institution. All subjects were informed of the purpose of the study and gave their informed consent to take part in the investigation.

\section{Study design}

All subjects underwent a nutritional, physical and laboratory examination to rule out any underlying disease. Fasting blood samples were used to determine basal plasma homocysteine levels; glucose, creatinine, folate, and vitamin $\mathrm{B}_{12}$ serum levels; and to identify C677T and A1298C MTHFR gene polymorphism. For the determination of the serum vitamin levels, samples were kept away from light. Plasma and serum samples were placed on ice and transported to the laboratory within $30 \mathrm{~min}$ of collection. Blood was centrifuged at $4^{\circ} \mathrm{C}(3,000 \mathrm{rpm}$, $10 \mathrm{~min}$ ), frozen and stored at $-70^{\circ} \mathrm{C}$ until analysis.

Right after collection of the fasting blood sample, methionine $\left(\mathrm{MERCK}^{\circledR}\right)$ was administered orally $(100 \mathrm{mg} / \mathrm{kg}$ body weight), diluted in $250 \mathrm{~mL}$ of mate tea (13). A new blood sample was collected 4 hours later for the determination of plasma homocysteine levels after methionine overload. After the first blood collection, volunteers ate a standardized methionine-poor breakfast and lunch, adding up a total of $0.9 \mathrm{~g}$ methionine (14).

\section{Nutritional and clinical evaluation}

Nutritional status was assessed by measuring weight, height and abdominal circumference using previously described techniques. Body mass index (BMI) was calculated as weight $/$ height $t^{2}\left(\mathrm{~kg} / \mathrm{m}^{2}\right)$ and subjects were considered to be overweight or obese when BMI was $\geq 25 \mathrm{~kg} / \mathrm{m}^{2}$. Normal values for waist circumference measurements were $102 \mathrm{~cm}$ for men and $88 \mathrm{~cm}$ for women (15). The composition of the habitual diet was based upon the Semi-Quantitative Food Frequency Questionnaire. Folate, vitamin $\mathrm{B}_{6}$ and $\mathrm{B}_{12}$ intakes were determined over the six-month period preceding the study, by means the software NutWin Profissional ${ }^{\circledR} 1.5$ (Universidade Federal de São Paulo - Unifesp, São Paulo, Brazil). Glycemia was determined by the orthotoluidine method using a LABTEST $^{\circledR}$ kit, with normal 
values below $100 \mathrm{~mL} / \mathrm{dL}$. Serum creatinine was determined by colorimetry using a LABTEST ${ }^{\circledR}$ kit, with normal values below $1.5 \mathrm{mg} / \mathrm{dL}$. Folate (reference range $3.0-17.0 \mathrm{ng} / \mathrm{mL}$ ) and vitamin $\mathrm{B}_{12}$ (reference range $174.0-879.0 \mathrm{pg} / \mathrm{mL}$ ) were measured by chemoluminescence in a competitive solid phase enzymatic assay using the IMMULITE 2000 kit (DPC ${ }^{\circledR}$ MEDLAB).

\section{Homocysteine assay}

Plasma homocysteine was measured by automated high performance liquid chromatography (HPLC) with fluorescence detection (SHIMADZU, LC 9A) and a reverse-phase $\mathrm{C} 18$ column, using a specific kit (IMMUNDIAGNOSTIK ${ }^{\circledR}$, Germany). Fasting plasma homocysteine levels of $15.0 \mu \mathrm{mol} / \mathrm{L}$ or less were considered normal (16). The upper normal limits for homocysteine after methionine overload were based on the sum of the mean +2 standard deviations of the value detected in the control group (4), so that values lower than $44.2 \mu \mathrm{mol} / \mathrm{L}$ were considered normal.

\section{Analysis of MTHFR gene polymorphism}

Genomic DNA was extracted from peripheral blood leukocytes using the modified salting-out technique described by Miller, Dykes and Polesky (1988) (17). Genomic DNA segments were amplified by PCR. To determine the amplification of PCR products, $1 \%$ agarose gel (A-2790, Sigma) electrophoresis was performed using Tris-borate EDTA buffer and ethidium bromide staining. The amplified fragments were analyzed by restriction fragment length polymorphism (RFLP) (18). The C677T and A1298C polymorphisms were analyzed in the gene that encodes the enzyme MTHFR. C677T mutation was detected by amplification of the sequence corresponding to the polymorphic region of exon 4 flanked by the oligonucleotide (12), followed by digestion with the restriction enzyme Hinf I (Prome$\left.\mathrm{ga}^{\circledR}\right)$. Al298C mutation was determined by amplifying the polymorphic region in exon 7 and by digesting the product with the restriction enzyme Mbo II $\left(\mathrm{BioLab}^{\circledR}\right)$.

\section{Statistical analysis}

Data were analyzed statistically using the Statistical Analyses System (SAS) software version 9.0 (SAS Institute, Cary, NC). In the nutritional evaluation, categorical variables were compared by the chi-square test and are presented as proportions. We used Student t-test or Mann-Whitney test, according to normality of the va- riables. Results are presented as mean $\pm \mathrm{SD}$ (variables with normal distribution) or as median and range (variables with non-normal distribution). The associations between plasma homocysteine concentrations and polymorphism were tested using linear regression models. In order to satisfy the assumptions of the adjusted model, logarithmic transformation of the respective response variables was necessary. The model was adjusted according to age and gender. These results are reported as geometric means with $95 \%$ confidence interval $(95 \% \mathrm{CI})$. The level of significance was set at $\mathrm{p} \leq 0.05$ for all analyses.

\section{RESULTS}

\section{Nutritional and clinical evaluation}

Compared with healthy control subjects, patients of DM group had a higher prevalence of BMI $\geq 25 \mathrm{~kg} / \mathrm{m}^{2}$ and abdominal circumference exceeding normal values (Table 1). Folate, vitamin $\mathrm{B}_{6}$ and $\mathrm{B}_{12}$ intakes were similar in both groups. Although there was a significant difference in serum creatinine, folic acid and vitamin $B_{12}$ between groups, all volunteers were within the normal range regarding these parameters. Even though the DM group was being regularly followed up in the outpatient clinic, their glycemic levels were not properly controlled at the time of the evaluation.

\section{Plasma homocysteine under basal conditions and after a methionine overload}

There was no significant difference between DM and control subjects in fasting homocysteinemia or after methionine overload (Table 1). Despite the tendency towards higher percentage of individuals with increased fasting plasma homocysteine levels among the diabetic patients ( $40.0 \%$ vs. $23.1 \%, \mathrm{p}=0.06$ ), hyperhomocysteinemia after the methionine overload was similar in the two groups.

\section{Homocysteine according to MTHFR gene polymorphisms}

Heterozygote and homozygote C677T mutation frequencies were $49.0 \%$ and $13.7 \%$ in diabetic patients, versus $48.1 \%$ and $7.4 \%$ in control subjects, in HardyWeinberg equilibrium ( $\mathrm{p}=\mathrm{NS}$ between groups). The heterozygote and homozygote Al298C mutation frequencies were $27.5 \%$ and $5.9 \%$ in diabetic patients, versus $44.4 \%$ and $5.6 \%$ in control subjects, respectively ( $\mathrm{p}$ $=$ NS between groups). 
Table 1. General characterization of individuals with diabetes mellitus (DM) and controls subjects

\begin{tabular}{|c|c|c|}
\hline Variables & $\begin{array}{l}\text { DM Group } \\
(n=50)\end{array}$ & $\begin{array}{l}\text { Control Group } \\
(n=52)\end{array}$ \\
\hline Age (years) ${ }^{*}$ & $48.2 \pm 7.6$ & $38.9 \pm 8.6$ \\
\hline Gender (female/male ratio) & $35 / 15$ & $30 / 22$ \\
\hline $\mathrm{BMI}\left(\mathrm{kg} / \mathrm{m}^{2}\right)^{\star}$ & $29.5(22.5-51.7)$ & $26.4(17.9-40.6)$ \\
\hline $\mathrm{BMI} \geq 25 \mathrm{~kg} / \mathrm{m}^{2}[\mathrm{n}(\%)]^{*}$ & $44(88.0)$ & $32(61.5)$ \\
\hline $\begin{array}{l}\text { Increased abdominal } \\
\text { circumference }[\mathrm{n}(\%)]^{*}\end{array}$ & $39(78.0)$ & $21(40.4)$ \\
\hline \multicolumn{3}{|l|}{ Usual nutrient intake } \\
\hline Folate (mg/day) & $193.5 \pm 83.2$ & $181.9 \pm 63.9$ \\
\hline Vitamin $B_{6}$ (mg/day) & $1.3 \pm 0.5$ & $1.5 \pm 0.5$ \\
\hline Vitamin $B_{12}(\mu \mathrm{g} /$ day $)$ & $3.9(0.6-31.4)$ & $5.4(1.3-31.0)$ \\
\hline Fasting blood glucose (mg/dL) ${ }^{*}$ & $158.3(53.0-404.0)$ & $79.6(62.9-113.3)$ \\
\hline Serum creatinine $(\mathrm{mg} / \mathrm{dL})^{\star}$ & $1.0 \pm 0.2$ & $0.9 \pm 0.2$ \\
\hline Serum folate $(\mathrm{ng} / \mathrm{mL})^{*}$ & $9.3(4.0-16.7)$ & $10.8(5.7-20.4)$ \\
\hline Serum vitamin $B_{12}(p g / m L)^{*}$ & $409.5(211.0-1200.0)$ & $334.0(179.0-887.0)$ \\
\hline Homocysteine preload ( $\mu \mathrm{mol} / \mathrm{L})$ & $12.8(3.7-33.3)$ & $11.9(6.7-37.1)$ \\
\hline Homocysteine afterload ( $(u \mathrm{~mol} / \mathrm{L})$ & $34.0(11.4-30.9)$ & $30.1(13.1-84.0)$ \\
\hline \multicolumn{3}{|l|}{$\begin{array}{l}\text { Number with } \\
\text { hyperhomocysteinemia (\%) }\end{array}$} \\
\hline Preload $>15.0 \mu \mathrm{mol} / \mathrm{L}$ & 40.0 & 23.1 \\
\hline Afterload $>44.2 \mu \mathrm{mol} / \mathrm{L}$ & 24.0 & 13.5 \\
\hline
\end{tabular}

${ }^{*} p<0.05$; mean $\pm S D$ for variables with normal distribution; median (minimum-maximum) for variables with non-normal distribution.

The distribution of homocysteinemia under fasting conditions according to enzyme MTHFR gene polymorphisms in the two groups is shown in Table 2. Considering the same polymorphism, there was no difference in plasma homocysteine values between diabetic patients and healthy control subjects. However, plasma homocysteine concentrations were significantly lower in the DM group $(\mathrm{p}=0.04)$ in the presence of $\mathrm{A} 1298 \mathrm{C}$ polymorphism than in the presence of C677T gene polymorphism. In the Control group, homocysteine levels were higher among individuals with polymorphisms (alone or in combination) than among individuals without polymorphisms.

\section{DISCUSSION}

In this study, there was a trend towards a greater number of subjects presenting fasting hyperhomocysteinemia in the DM group than in the Control group. There was no difference in plasma homocysteine levels between diabetic and control subjects according to each MTHFR gene polymorphism. On the other hand, homocysteine levels varied among the different polymorphisms within each study group. Plasma homocysteine concentration was lower among control individuals with no polymorphisms than among individuals with separate or associated polymorphisms. Among diabetic patients, homocysteine levels were lower in the presence of Al298C polymorphism than in the presence of C677T gene polymorphism.

Our results are in agreement with data reported in the literature showing that A1298C polymorphism alone is not associated with hyperhomocysteinemia $(19,20)$. It has been shown that the effect of this mutation is more relevant when serum folate levels are low (21), or when the mutation is associated with C677T polymorphism (22). When compared with subjects with A1298C polymorphism, homozygotes with C677T polymorphism presented greater reduction of MTHFR activity, lower plasma folate levels, and more marked hyperhomocysteinemia $(20,22,23)$.

Lack of correlation between C677T mutation and the homocysteine levels suggest that environmental and other genetic factors seem to have greater influence on homocysteine levels in patients with coronary atherosclerotic disease (24). Mazza and cols. (25) described that, in the absence of nephropathy, fasting homocysteine levels were not related to C677T MTHFR genotype, but were inversely related to glycemia.

Reduced peripheral resistance to insulin has been considered responsible for lower plasma homocysteine levels in the initial phases of experimental diabetes $(26,27)$, due to increased transsulfuration (28). On the other hand,

Table 2. Geometric means and confidence intervals $(95 \% \mathrm{Cl})$ of fasting plasma homocysteine levels (mmol/L) according to MTHFR genotype in the diabetes mellitus (DM) and control groups

\begin{tabular}{|c|c|c|c|c|}
\hline \multirow{2}{*}{ MTHFR polymorphisms } & \multicolumn{4}{|c|}{ Plasma homocysteine level ( $\mu \mathrm{mol} / \mathrm{L}) \#$} \\
\hline & $\mathbf{n}$ & DM Group & $\mathbf{n}$ & Control Group \\
\hline Absence C677T or A1298C & 9 & $12.3(9.6-15.8)$ & 9 & $8.9(7.0-11.5)$ \\
\hline C677T (alone) & 25 & $14.4(12.3-16.9)$ & 18 & $11.5(9.6-13.7)^{b}$ \\
\hline A1298C (alone) & 10 & $10.4(8.2-13.1)^{\mathrm{a}}$ & 13 & $13.6(10.9-16.8)^{c}$ \\
\hline C677T + A1298C (in combination) & 6 & $15.0(11.1-20.4)$ & 12 & $12.5(10.1-15.4)^{d}$ \\
\hline
\end{tabular}

\# After adjustment for age and gender.

${ }^{a} p \leq 0.05$ between A1298C vs. C677T polymorphisms in the DM group; ${ }^{b} p \leq 0.05$ between C677T polymorphism vs. no polymorphisms in the Control group; ${ }^{\mathrm{c}} \mathrm{p} \leq 0.05$ between A1298C polymorphism vs. no polymorphisms in the Control group; ${ }^{\circledR} p \leq 0.05$ between C77T+A1298C polymorphism vs. no polymorphisms in the Control group. 
variations in serum homocysteine levels were not related with insulin, proinsulin, and insulin sensitivity among the Parkatêjê Indians (29). Hyperglycemia has a hyperosmolar effect that enhances glomerular filtration and may increase urinary excretion of homocysteine (30). This mechanism may have been responsible for the similarity between the DM and Control groups regarding homocysteinemia medians in this study.

It is possible that the small sample size limited analysis to MTHFR gene polymorphisms. Epidemiological studies of genetic polymorphism require large samples, especially for the evaluation of hyperhomocysteinemia as a risk factor for chronic complications $(2,7,10)$. On the other hand, even when conducted on a reduced number of patients, clinical studies can point out changes in the metabolic pathways of homocysteine $(4,28)$. The absence of data related to serum concentrations of vitamin $\mathrm{B}_{6}$ and genetic polymorphisms of other enzymes involved in homocysteine metabolism, especially those of the transsulfuration pathway, are some of the limitations of the present study.

In conclusion, this study shows that homocysteine plasma levels (before or after methionine load) were similar between diabetic patients and healthy controls, although hyperhomocysteinemia was more common among the diabetic patients. The presence of polymorphisms in the MTHFR genes resulted in increased homocysteine plasma levels among control subjects. Among diabetic patients, the only finding was that the A1298C polymorphism resulted in lower homocysteinemia when compared with C677T. The different outcomes between diabetic patients and control individuals suggest that the diabetic metabolic environment may be involved in the metabolism of homocysteine, regardless of MTHFR polymorphisms.

Grant support: This study was supported by a grant from Conselho Nacional de Desenvolvimento Científico (CNPq), and by Coordenação de Aperfeiçoamento de Pessoal de Nível Superior (Capes).

Disclosure: no potential conflict of interest relevant to this article was reported.

\section{REFERENCES}

1. DECODE Study Group. European Diabetes Epidemiology Group. Is the current definition for diabetes relevant to mortality risk from all causes and cardiovascular and noncardiovascular diseases? Diabetes Care. 2003;26(3):688-96.

2. Soedamah-Muthu SS, Chaturved N, TeerlinkT, Idzior-Walus B, Fuller JH, Stehouwer CD; Eurodiab Prospective Complications Study Group. Plasma homocysteine and microvascular and macrovascular complications in type 1 diabetes: a cross-sectional nested case-control study. J Intern Med. 2005;258(5):450-9.
3. Vannucchi H, Melo SS. Hiper-homocisteinemia e risco cardiometabólico. Arq Bras Endocrinol Metab. 2009;53(5):540-9.

4. Hofmann MA, Kohl B, Zumbach MS, Borcea V, Bierhaus A, Henkels $M$, et al. Hyperhomocyst(e)inemia and endothelial dysfunction in IDDM. Diabetes Care. 1998;21(5):841-8.

5. Selhub J, Jacques PF, Wilson PW, Rush D, Rosenberg IH. Vitamin status and intake as primary determinants of homocysteinemia in an elderly population. JAMA. 1993;270(22):2693-8.

6. Xu Z, Prathapasinghe G, Wu N, Hwang SY, Siow YL OK. Ischemia-reperfusion reduces cystathionine-beta-synthase-mediated hydrogen sulfide generation in the kidney. Am J Physiol Renal Physiol. 2009;297(1):F27-35.

7. Orzechowska-Pawilojc A, Sworczak K, Lewczuk A, Babinska A. Homocysteine, folate and cobalamin levels in hypothyroid women before and after treatment. Endocr J. 2007;54(3):471-6.

8. Ventura P, Panini R, Emiliani S, Salvioli G. Plasma homocysteine after insulin infusion in type II diabetic patients with and without methionine intolerance. Exp Clin Endocrinol Diabetes. 2004;112(1):44-51.

9. Aras $\mathrm{O}$, Hanson NQ, Yang F, Tsai MY. Influence of $699 \mathrm{C}-->$ T and $1080 \mathrm{C}$-->T polymorphisms of the cystathionine beta-synthase gene on plasma homocysteine levels. Clin Genet. 2000;58(6):455-9.

10. Cortese C, Motti C. MTHFR gene polymorphism, homocysteine and cardiovascular disease. Public Health Nutr. 2001;4(2B):493-7.

11. Tsai MY, Bignell M, Yang F, Welge BG, Graham KJ, Hanson NQ. Polygenic influence on plasma homocysteine: association of two prevalent mutations, the 844 ins 68 of cystathionine beta-synthase and $A(2756) G$ of methionine synthase, with lowered plasma homocysteine levels. Atherosclerosis. 2000;149(1):131-7.

12. Frosst $P$, Blom HJ, Milos R, Goyette $P$, Sheppard CA, Matthews $R G$, et al. A candidate genetic risk factor for vascular disease: a common mutation in methylenetetrahydrofolate reductase. Nat Genet. 1995;10(1):111-3.

13. Krupková-Meixnerová L, Veselá K, Vitová A, Janosíková $B, A n-$ del $M$, Kozich V. Methionine-loading test: evaluation of adverse effects and safety in an epidemiological study. Clin Nutr. 2002;21(2):151-6.

14. den Heijer M, Bos GM, Brouwer IA, Gerrits WB, Blom HJ. Variability of the methionine loading test: no effect of a low protein diet. Ann Clin Biochem. 1996;33 (Pt 6):551-4.

15. Han TS, van Leer EM, Seidell JC, Lean ME. Waist circumference action levels in the identification of cardiovascular risk factors: prevalence study in a random sample. BMJ. 1995;311(7017):1401-5.

16. Akbari A, Dehbozorgian J, Afrasibi AR, Gafari H, Gerdabi J, Karimi $M$. Frequency of afterload homocysteinemia in normal population of Southern Iran: a pilot study. Pak J Biol Sci. 2010;13(7):352-4.

17. Miller SA, Dykes DD, Polesky HF. A simple salting out procedure for extracting DNA from human nucleated cells. Nucleic Acids Res. 1988;16(3):1215.

18. Watkins PC. Restriction fragment length polymorphism (RFLP): applications in human chromosome mapping and genetic disease research. Biotechniques. 1988;6(4):310-9, 322.

19. Hanson NQ, Aras O, Yang F, Tsai MY. C677T and A1298C polymorphisms of the methylenetetrahydrofolate reductase gene: incidence and effect of combined genotypes on plasma fasting and post-methionine load homocysteine in vascular disease. Clin Chem. 2001;47(4):661-6.

20. Friedman G, Goldschmidt N, Friedlander $Y$, Ben-Yehuda A, SeIhub J, Babaey S, et al. A common mutation A1298C in human methylenetetrahydrofolate reductase gene: association with plasma total homocysteine and folate concentrations. J Nutr. 1999;129(9):1656-61.

21. Weisberg IS, Jacques PF, Selhub J, Bostom AG, Chen Z, Curtis Ellison $\mathrm{R}$, et al. The $1298 \mathrm{~A}->\mathrm{C}$ polymorphism in methylenete- 
trahydrofolate reductase (MTHFR): in vitro expression and association with homocysteine. Atherosclerosis. 2001;156(2):409-15.

22. Weisberg I, Tran P, Christensen B, Sibani S, Rozen R. A second genetic polymorphism in methylenetetrahydrofolate reductase (MTHFR) associated with decreased enzyme activity. Mol Genet Metab. 1998;64(3):169-72.

23. Hiraoka M, Kato K, SaitoY, Yasuda K, KagawaY. Gene-nutrient and gene-gene interactions of controlled folate intake by Japanese women. Biochem Biophys Res Commun. 2004;316(4):1210-6.

24. Muniz MT, Siqueira ER, Fonseca RA, D'Almeida V, Hotta JK, dos Santos JE, et al. Evaluation of MTHFR C677T gene polymorphism and homocysteine level in coronary atherosclerotic disease. Arq Bras Endocrinol Metabol. 2006;50(6):1059-65.

25. Mazza A, Giugliano D, Motti C, Cortese C, Andreotti F, Marra G, et al. Glycemia, MTHFR genotype and low homocysteine in uncomplicated type 2 diabetic patients. Atherosclerosis. 2000;149(1):223-4.
26. Wijekoon EP, Hall B, Ratnam S, Brosnan ME, Zeisel SH, Brosnan JT. Homocysteine metabolism in ZDF (type 2) diabetic rats. Diabetes. 2005;54(11):3245-51.

27. Ratnam S, Wijekoon EP, Hall B, GarrowTA, Brosnan ME, Brosnan JT. Effects of diabetes and insulin on betaine-homocysteine S-methyltransferase expression in rat liver. Am J Physiol Endocrinol Metab. 2006;290(5):E933-9.

28. Abu-Lebdeh HS, Barazzoni R, Meek SE, Bigelow ML, Persson XM, Nair KS. Effects of insulin deprivation and treatment on homocysteine metabolism in people with type 1 diabetes. J Clin Endocrinol Metab. 2006;91(9):3344-8.

29. Tavares EF, Vieira-Filho JPB, Andriolo A, Franco LJ. Relationship of homocysteine, insulin sensitivity and cardiovascular risk factors among the Brazilian Parkatêjê Indians. Arq Bras Endocrinol Metab. 2002;46(3):260-8.

30. Wollesen F, Brattström L, Refsum H, Ueland PM, Berglund L, Berne C. Plasma total homocysteine and cysteine in relation to glomerular filtration rate in diabetes mellitus. Kidney Int. 1999;55(3):1028-35. 